\title{
Four Dimensions of Benign Political Ecology Construction
}

\author{
An HUANG ${ }^{1,{ }^{*}}$ and Hong-bang ZHANG $^{1}$ \\ ${ }^{1}$ Xi'an Jiaotong University, Marxism School, Shannxi Xi'an 710049 \\ *Email: anhare9703@stu.xjtu.edu.cn
}

\begin{abstract}
Keywords: Political ecology, Agenda setting, Supervision by public opinion, Guidance of public opinion.
\end{abstract}

\begin{abstract}
Under the trend of communication network gradually flattening, media has become the condition of democratic politics operating and builder of political discourses. From the relationship of media and politics, based on some classical theories such as ears and eyes, agenda setting, supervision by public opinion, guidance of public opinion, it can be found that in the construction of benign political ecology, political open has become premise by ear and eye, political participation play as approach because of agenda setting, political repair considers itself as safeguard under supervision of public opinion, political coordination serve as means with guidance of public opinion. The processes of benign political ecology construction can't do without the constructive role of media. Political open, political participation, political repair and political coordination are the main dimensions of building benign political ecology, which is also a course of government, society and public open information, participate decision, coordinate direction, repair divergence with the help of media.
\end{abstract}

\section{Introduction}

Political ecology is a new perspective which uses ecological thought, logic and method to observe and analyze political field. It considers the ecology linkage law, which could link, restrict, and effect different factors in political system. On June $30^{\text {th }}$, 2014, Xi Jin-ping, the CPC Secretary General indicated, "Strengthening ruling party building must have a sound ruling situation, namely, having a benign political ecology". Thus, the issue, which built a political ecology system oriented by well-being as well as considered the harmonious development among citizens, society and nation, has become a realistic problem faced by many scholars. But, in reality, there exists some drawbacks, such as "insufficiency of definition in political power structure, obstruction of operation in systemic ecology, poor of efficiency in supervisory mechanism" [1]. Because of absence in supervisory mechanism, some officers have the tendency of "moral emptiness" [2].

Plato compared nation as an individual. Besides, "a country which can operate harmoniously just like an organism whose parts connect closely"[3]. This can be seen as the primal judgment on political ecology construction. Recently, relevant domestic researches mainly focus on three aspects: First, political states are regarded as dynamic entirety. Comparative politics analyzes political ecology by structure-function analysis theory which contains system, process, policy and evaluation. It explores "ecological politics development path and its evaluation system, having regularity and scientificity" [4]. Simultaneously, comparative politics sees political state as a dynamics entirety. The objective effect of system implementation is criteria, which could create "relevant system and mechanism meeting social need and equity in general" [5]by perfecting nation's social 
management system, tamping ecological culture foundation alleviating social hostility, realizing "ecological interaction and boom" in every social strata. Secondly, great attention is paid on the adaptive capacity of administrative system. Gaus of Havard University is the first scholar to apply ecological viewpoint and methodology into studying political phenomenon. Fred Riggs then developed this theory in his administrative work (1961). Understanding administrative act must exceed administrative system itself to explore the interrelation between administrative system and externalities under the social situation, as well as discussing the way for administrative system to face and adapt environmental challenge. Wang hu-ning and Wang bang-zuo firstly introduced western ecological methodology into political academic realm in China. They try to inspect administrative operating mechanism by simulating ecological system, and study political special topic by applying ecological theory and methods. This perspective tries to transform traditional political value into nature environmental system. Moreover, it judged politics-society-nature as a trinity, explored functional mechanism of relevant factors under "the interrelation between political system and its environment" [6], studied developing venation about relevant phenomenon. Its target is to pursue ecological security, realize "ecological political civilization and political ecological civilization" [7]. Thirdly, China faces social transition dilemma. The transformation in China is a "very complicated social issue containing universality and exception" [8]. This "complex" political ecology involves adjustment on the ownership relation of social mechanism, faces urgent task of realizing modernization. Fourthly, media connects government, society and public. Some scholars see "politics can't do without media, media serves for politics" [9] as a relation maxim, pointing out that media connect the interrelation among government, society and citizens. Politics need the coordination of media and social mainstream values; simultaneously, media constricts the room of human political behavior through information transmission networks. The border of information spreading limits political act.

Relevant scholars performed helpful research on political ecology, meantime, provided more spaces to explore. Firstly, from the research perspective, the number of documents about politics, ecology and sociology are more than the numbers of political ecology under the background of the relationship between media and politics. Secondly, from the contents, most researches are limited to discuss political ecology itself and less focus on the building dimensionalities of political ecology. But, media is the product of politics development, and then accelerates it based on technical progress. Its relationship can't do without political ecological environment. The building of benign political ecology improves coordination and interaction among government, society, and public. Based on relevant researches and practices, it analyses the connotation, functions and interrelation of political open, political participation, political repair and political coordination in the benign political ecology construction.

\section{Political Open: Premise of Benign Political Ecology Construction}

Media is an institutional framework, having class nature. It belongs to superstructure, having responsibility to keep pace with mainstream value and its cultural orientation, which made media's eyes and ears functions prominent, namely, during the process of discussing political issues among citizens, society and nation, media are used to release political information, detect political environment, enhance political interaction, guide political opinions, affect the efficiency of political ecology construction. 
With the help of media as ears and eyes, political open meet the objective desirability of mass disturbance taking place frequently, interest appeal expressing dominantly, official's corruption becoming social hot spots. Considering government agency and social public, media could communicate information, detect environment, and guide opinion, which is an important pushing hands for enhancing the working efficiency of government body, propelling political restructuring. Only timely, effectively, objectively and fairly delivering information, it is possible for media to meet right to know, participate, express, supervise of the masses, realizing the integration of mass mobilization and social regulation. Furthermore, about column construction and content choice, media need to reinforce the grasp of communication law of social public opinion, the psychological features of netizens, made all types of media having more enthusiasm and initiative during the process of generating popular feelings and cultivating social consensus. Meanwhile, it is obvious that technological process made people having the right to freely share information, but appropriately exercising it rely on cultural background, psychological quality and institutional environment. Administrator's intervention, opinion leader' influence, group psychology's existence, irrational sentiments' expression, might lead to cyber-violence growing and spreading, weaken liberty, open and reason in the process of political open, form silent faultage, hinder the formation of objective and rational popular will. Media is a magnifying lens and megaphone, which could norm official acts of behavioral subject, optimize political ecological environment, safeguard democratic realization economic development.

After the convening of NPC \& CPPCC in 2015, the Xinhua News Agency issued features about Sip Kin-ping, Li Ke-Qiang and other politburo's standing committees through newspaper, magazine, Internet. The features include their personal information, family background and work experience, reflecting the kind attitude of the new leadership, contain profound "exemplar which promoting reform from top to bottom". From the perspective of communication, this technique contains "onmi-media and realizing all standing", obscure the perceived boundaries between public space and private space, optimize information acceptance channel, enlarge the contact area of public life, and provide choices to express views. All of these demonstrate the formation of objective and rational popular will relies on "unrestricted flow", namely, utilizing network platform, realizing integration of technological means and reporting content, expand personal discourse expression space, mobilizing citizens' political expression willingness. Just as Wen Hui Bao indicates, this series report embodies hyalinization of current political ecology, increases friendliness of governing for the people, driving political mechanism more openness. All of these demonstrates, if measures are used properly, Internet could open governing behavior, transmit policy information, collect public feelings, finally increasing social coordination and control during the transitional period.

As a premise of building benign political ecological system, political opening should become the information exchange mechanism among government, media and public, reflecting political undertakings of "power using for the people, sentiment caring for the people, interests seeking for the people". Realistic result could be attained only after translating into practical actions in the political participation.

\section{Political Participation: Approach of Benign Political Ecology Construction}

As a social instrument, media is a place of political debate, a tool of political participation. This relationship made media having agenda-setting function, called by Maxwell McCombs and Shaw. According to quantitative researches about presidential 
election of U.S.A in 1968, they concluded that strong correspondence exists between the judgment of electors about current hot issue and relevant news and key points reported by media. Namely, the great event reported by media is also reflected in public's awareness; the more media emphasize the more public concern. Hereby, McCombs and Shaw consider that mass media have the function of setting agenda for social public affairs.

Political participation refers to such political behavior that citizen orderly takes part in political life, expresses political will, perfects political ecology through mass media, abiding by "people must take part in decision-making process which could impacting their lives"[10]. During this process, media "agenda-setting" function reflected in selective reporting hot issue, guiding citizens impartially participating in public affairs, free idea, equal identity, collaborative ways, using rational thinking to criticize social events. Concretely abstract issues are decomposed into concrete issues, help audiences understanding its connotation, whoever they have different knowledge background, social experience and living environment. This method "prompts public turn their attention to some specific topic; media helps politicians erecting public images, then continually reports it, implying public to think it, understand it and feel it"[11]. Among these, abstract issue refers such macro-scopical issues, involving national long-term development, for example, and rule by law, new normal. But those involving national welfare and the people's livelihood, such as fighting both "tigers" and "flies", "household registration reform", are concrete issues. Media planners translate abstract issues into concrete issues available by rendering official language into media language, making relevant policy information spreading out.

With the increasing of political participation awareness, the NPC \& CPPCC are platform for political participation by all orders of society using social media, and also a stage for media giving all kinds of issues various significance to effect public know political ecology. There are three aspects about coding and narration on content: firstly, collect popular will from bottom to top. Mass media opens up relevant special columns through social media, such as "entrust governor and secretary taking a word", "synchronously comment", "legal person micro-blog", to collect popular will and attend to people's livelihood. People's participation enthusiasm can also be released by "comment" and "share" attached in news webpage. Communication research demonstrates that keeping constant attention on the same topic will form public opinion, which will broaden people's political participation, and heighten report coverage. Secondly, guide public opinion from top to bottom. Xinhuanet synthesizes past focus to issues "Top Ten Hotspots about NPC \& CPPCC in 2015" (see Table 1), publicly setting topic for discussing and guiding orderly political participation.

Table 1 Top Ten Hotspots about NPC \& CPPCC in 2015.

\begin{tabular}{ll} 
number & content \\
First & deepen reform: streamline administration and institute decentralization in the key year \\
Second & rule by law: promote reform through lawmaking in the opening year \\
Third & new normal in economy: speed downward and quality upward \\
Forth & anti-corruption and pro-honesty: treat both symptoms and root causes by law. \\
Fifth & environmental management: assess administrator's work by strictly law enforcement \\
Sixth & finance and tax reform: clean "excess taxes and dues" to richen people \\
Seventh & focus on "issues of agriculture": activate rural "sleeping capital". \\
Eighth & pension system reform: controversy about refining "integration"measures. \\
Ninth & employment and pioneering: surge of both "the tide of masses pioneering" and "the \\
& tide of scientific and technical innovation". \\
Tenth & $\begin{array}{l}\text { great power diplomacy: "One Belt One Road" start omnibearing pattern opening to } \\
\text { the outside world }\end{array}$ \\
\hline assorted data by http://www.xinhuanet.com/.
\end{tabular}


Thirdly, define or conclude. Communication theories consider "define", "conclude" could emphasize the importance of particular agenda, and guiding masses accept it. Premier minister Li ke-Qiang's government work report become authoritative public opinion, then forming mainstream opinion abiding by all social members, after taking in suggestions of representatives and committee members and social appealing of ordinary people. For example: "the phenomena of economic speed slowing down, but newly increased employment increasing, demonstrates the huge power of reform and infinite potential of market", "promote growth, increase employment, adjust structure have become international consensus".

Social development broaden approaches for participating building political ecology, presenting a serial of new tendencies, namely, the entry of new stratum enlarge political participation subject, the rise of social media optimize political participation tools, the growth of interest expression clear the tendency of participation motivation secularization. All of these brought pressure and motive on constant and effective operation of political system, proposing new higher demands for governmental agencies updating political idea, adjusting governing behavior, replying new-time challenges, advancing service-oriented government construction.

\section{Political Repair: Safeguard of Benign Political Ecology Construction}

The influence of media on politics manifests the fact that media could supervise and restrict the distribution and redistribution of political power. Media has political attribute, but media should not attached on power. Oppositely, the operation of media should effectively avoid the disturbance of political power, and then supervise it.

The original meaning of repair refers to the process of mending and recovering by organism impaired cells and tissues. In the process of building political ecology, realizing benign political repair needs that ruling class faces systematic malpractice, supervising by public opinion, remedying by political measures. Media is an open channel for public to know information, voice opinions. Supervision by public opinions is an instrument for public safeguard their own rights through exercising expression rights and veto power by media. With social developing consciousness of civil right increasing, media is playing a growing role in the making use of supervision by public opinions to overcome power "caprice", repair systematic malpractice. It could offer related bodies an opinion exchange platform for playing political function, releasing political energy. As a condition of political revolution and builder of political discourse, media is considered as a platform for public participation, concerning natural environment, understanding social situation, discussing public affairs. It has no compelling force, but could perform its supervisory duty through overcoming subjectivity, randomness and concealment occurred in the power operational process. The question whether relevant repairing mechanism effectively operates determines that people exercise democratic rights by law, realizing "a pathway for self-government, self-service, self-education, self-supervision" [12].

Because of desynchrony in political restructuring, deficiency in moral idea, corruption has taken place frequently, and the phenomena that civil servants plot private interests by utilizing faultiness should be the primary cause of degeneration of a nation [13]. "Tacitus Trap" is a theory proposed by ancient Rome historian Tacitus (A.D.55 120). It profoundly expounded that once the government lost credibility, "becoming a resentful object," will face vicious circle, namely "whatever done, good or bad, will equally arise aversion"[14]. Socialistic China leaded by Chinese Communist Party could effectively avoid this trap. Only resorting to supervision by 
public opinions, sounding social culture, add elastic control, it is possible to "develop itself under the situation of driving social progress, help social development in the process of improving itself", forming a virtuous circle enhancing government credibility[15]. This is a process in which each group in political system, facing conflict, fully excavate "individual mobility and social relations impetus"[16] resort to third-party board and supervision by public opinions, realizing re-balanced ecology. As the mouthpiece of CCP, mainstream media should reflect the unification of Party spirit and national character in enhancing credibility. For building a sound political atmosphere, propaganda ideological work, leaded by party committees, must "reinforce analysis and judgment about significant problems in propaganda ideology field, and also integration and guidance about significant strategic mission" in terms of the principle of CCP control over media, propagandize positive energy, highlight the theme, enlarge expression channel, cement the guiding role of Marxism in ideology realm.

Social principal contradiction determines the future direction. Currently, the fall between increasingly material and cultural needs and laggard productivity makes up the main social contradiction in China. From the perspective of building benign political ecology, the contradiction lies in systematic malpractice existed in social development and profit distribution imbalance caused by imperfection in reform, which is minor problem on the road of comprehensively deepen reform. Perfecting relevant repair mechanism is a powerful safeguard for building political ecology.

\section{Political Coordination: Means of Benign Political Ecology Construction}

Media is a common platform that government, social, and public express opinion, reach consensus about concerned political issues. This relationship makes the role of direction of opinion guidance in building benign political ecology prominent. Opinion guidance refers to a process that mass media considers "guide people with correct public opinion" as reporting idea; using media means to coordinate realistic interest demand from psychological and sentimental aspects by universal consensus, scientific content and perfect formal.

Political coordination is administrative guarantee to realize consistently public management. "The difference between one government and the another lies in the degree of market replacing government" [17]. The media's duty is to unite individual cognizance and public feelings, urging value identification arising in public and enhancing the coordination of political ecology system. Individual attitude should undergo a process of psychological adjustment, namely 'passive compliance --voluntary accept --- thorough transformation.' Current society is undergoing medium massification, information fragmentation, communication diversification; narrative method, critical angle of medium could change social public opinion, and influence the masses' value idea and behavior choice. Therefore, media needs to concern social situation, and effectively guide it by receivers' trait, especially mediate conflict, from social media's function as reducing valve, finally realizing 'cross-census'. Finally, multiplex interest bodies can co-exist and reasonable appeal can be met. Only after having effective political coordination, erecting synergetic development idea, strengthening consistency between media and politics, improving social satisfaction for benign political ecology construction, compromise could be possible, ecology could avoid falling apart, and human society could have persist reproduction.

Dengzhou Pattern was firstly raised in Zhengzhou, Henan Province in 2004, and then popularized by Henan provincial Party committee. It also has been affirmed by center leaders. Dengzhou Pattern is a set of feasible procedures and institutions, which 
has institutional bodies such as village Party branch, village committee, Party convention, villagers' representative conference and villagers assembly, and connects by several links such as 'propose -- discuss -- examine -- decide --conclusion disclose -- results disclose'(see Figure 1). The essence of Dengzhou Pattern lies in exerting the zeal of village-level democratic autonomy and then promoting 'New Rural Construction'. Convincing theory of Communication considers that those who have less education are apt to be persuaded under others' influence. The implementation of Dengzhou pattern meets zeal of villagers, which coordinate respective difference, realizing political participation while managing village-level government affairs in links such as 'propose', 'discuss' 'examine', and insure corresponding effect through 'decide', 'conclusion disclose' and 'results disclose'. Meanwhile, all of these were finished under media cover and public supervision, conforming to democratic centralism. Recently, other forms of public political participation such as Wukan Practice and Wenling communion pattern ensure citizens' democratic rights. Specifically, during the process of public interest intensification, populace solve differences through coordinating and operating, spread positive energy through news coverage, and then making 'citizenship awaken because personal learn the way to have public thinking because of political action'[18], consciously transform self-interest into interaction activities among political subjects.

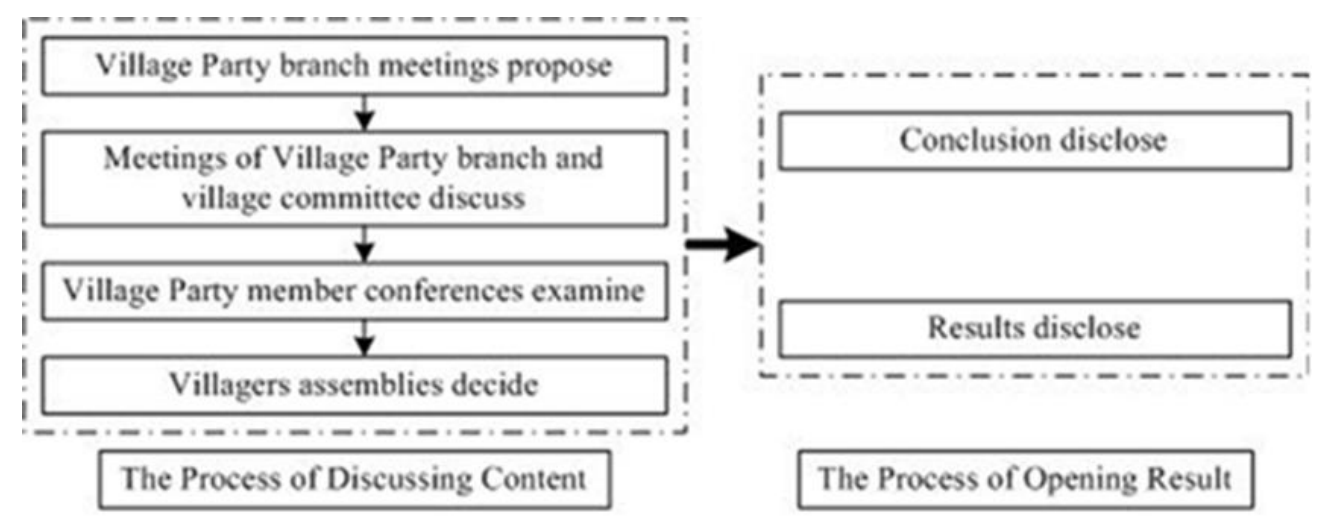

Figure 2 The Process of Discussing Content and Opening Result

During the social transition, constructional pressure inevitably reflected daily political life. Decompression function of mass media could relieve it by lifting receiver's status. The coordination relationship between political subjects can be advanced if developing risk can be evaded through coordinating social dispute, guide social emotion. The quality of political ecology can be directly related to the perfection degree of political system and its coordination function, as well as direction of public direction in a nation.

\section{Conclusion}

The establishment, maintenance and improvement of benign political ecology are a sophisticated project, which cannot do without thought and information exchange by virtue of media. During this process, media broaden political open by functions such as ears and eyes, promote political participation with the help of agenda setting, and reinforce political coordination through public opinion guidance, perfect political repair using public opinion supervision. This need summarize practice to "make perceptual knowledge rationalization, successful experiences systematize and valid practices institutionalization" [19]. Benign political ecology proposes ecologic value pursuit such as validity, stability, effectiveness and probity for its systematicness, 
integrality, equilibrium, dynamics. This pointing affects and stipulates the objective, direction and content of political ecology construction. Mass media should firstly insist the theme, and then bridge difference in opinion, tolerate diversification, as well as providing platform for collision in thought, allowing free competition in viewpoints, which should be specific reflection of benign political ecology.

\section{Acknowledgement}

This research was financially supported by the National Social Foundation of China "Research on Synergetic Development of Social Media and Political Ecology (Project number: 14BXW052)"

\section{References}

[1] Shen, Jianlin. Diagnosis Three Crucial Point of Political Ecology in China. People's Tribune, (2014) .No.25, pp.57.(In Chinese)

[2] Zheng, Yongnian. Anxiety about the Political Ecology in Grass-Root Society. Get along together, (2009). No.7, pp.9. (In Chinese)

[3] Plato. The Republic(Trans.). Beijing: Commercial press, (1986).pp.197. (In Chinese)

[4] Xia, Meiwu. Research on Contemporary Chinese Political Ecological Construction --- Based on Construe Function Analysis Perspective. Soochow University Doctoral Dissertation, (2014).pp.13. (In Chinese)

[5] Liu Jingxi, Wang Caixia. The Idea of Civil Society and the Construction of Harmonious Society --- from the perspective of political ecology. Zhejiang Academic Journal, (2007).No.02, pp.131-136. (In Chinese)

[6] Sang, Yucheng. Political Ecology in Political Development. Academic Monthly, (2012) No.08, pp.5-13. (In Chinese)

[7] Fang, shinan. Political Implications of Ecological Security from the Perspective of Ecological Politics. Social Sciences in Nanjing, (2012).No.03, pp.60-66. (In Chinese)

[8] Qiao, Yaozhang. Analysis of Political Ecology caused by Social Transformation Trap. Journal of the Provincial Level Party School of CPC Sichuan Province Committee, (2012).No.06, pp.40-48. (In Chinese)

[9] Yang na. The Relationship between Mass Communication and Politics. Journal of Graduate School of Chinese Academy of Social Sciences, (2008).No.06, pp.80. (In Chinese)

[10]John Naisbitt. Megatrends --- Ten New Directions Transforming Our Lives. Xinhua Publishing House. (1984). (In Chinese)

[11]Werner J. Severin, James W. Tankard. Communication Theories: Origins, Methods, and Uses in the Mass Media(Trans.). Huaxia Publishing House. (2001).pp.248, 259(In Chinese) 
[12] Lu Yang, Li Jingping. Marx's Cheap Government Theory and its value. Seeker, (2011).No.7, pp.47-49. (In Chinese)

[13] Zhang Hanqing, Immortal Document about Defending and Developing Proletarian Dictatorship Theory --- Memory of Engels "<the French Civil War> Introduction” Published 100 years ago, (1991).No.2, pp.93-97. (In Chinese)

[14] Publius Cornelius Tacitus. History(Trans.). Beijing: Commercial Press. (1981). pp.7. (In Chinese)

[15] LI Ming-de, WANG Xiao-feng, MENG Sheng-jun. Deviation and Reconstruction of Leading Responsibility of Mass Media --- Taking the main hotspot events from 2008 to 2011 as an example. Journal of Xi' an Jiaotong University (Social Sciences), (2012). No.06, pp.113-120. (In Chinese)

[16] Michael Baurmann. The Market of Morality(Trans.). Beijing: China Social Sciences Press. (2003)

[17] Charles E. Linblom. Political and Market: the Political - Economic System of the World. Shanghai: Shanghai People's Publishing House. (1994).pp.1

[18] Yuan Jianjun, Jin Taijun. Interpretation of the Core Elements of Participatory Democracy and Its Enlightenment. Studies on Marxism, (2011). No.05, pp.93-102. (In Chinese)

[19] Dang Pingwen. Create a Good Environment for Politics. School Party Construction and Ideological Education, (2014) .No.16, pp.1.(In Chinese) 